\title{
The Eficacy of Fiscal Policy in Promoting Economic Growth and Reducing Poverty in Nigeria
}

\author{
Kayode Asaju ${ }^{1}$, Sunday Onah Adagba ${ }^{1} \&$ Thomas John Kajang ${ }^{2}$ \\ ${ }^{1}$ Department of Political Science, Federal University, Wukari, Nigeria \\ 2 Department of Public Administration, Nuhu Bamalli Polytechnics, Zaria, Nigeria \\ Correspondence: Dr. Kayode Asaju, Department of Political Science, Federal University, Wukari, P.M.B 1020, \\ Wukari, Nigeria. Tel: 234-803-599-2503.E-mail: asajuk@gmail.com
}

Received: July 28, 2013

doi:10.5430/rwe.v5n1p65
Accepted: October 3, 2013

Online Published: March 2, 2014

URL: http://dx.doi.org/10.5430/rwe.v5n1p65

\begin{abstract}
Over the years, fiscal policy has been the most important instrument for influencing macroeconomic performance in Nigeria. The paper attempts to examine if the federal government has been able to effectively use this instrument to enhance economic growth and reduce poverty in Nigeria. Using secondary data from relevant government institutions, books, journals and newspapers, the paper shows that within the year under review, aggregate growth has been slow and sectoral growth uneven. Also, the incidence of poverty has continued to rise. These situations have been attributed to ineffective fiscal policy implementation and lack of budget discipline. The inflationary rate has continued to accelerate and the budget deficit is higher. Also recurrent expenditure has continued to take a larger portion of the total expenditure, causing the increase in the nation's debt profile. The non-oil sector contribution to the nation's revenue has not improved and there is still high incidence of extra-budgetary allocation. These are contrary to the fiscal objectives within the years under review. The paper suggested that government should put in place measures to ensure strict budget discipline, not only at the federal level, but also at the state and local government levels. The efforts of the government in curbing corruption should be strengthened. Also the government should ensure policy consistency and continuity and this should be taken into consideration in the formulation and implementation of budgets. The PPB is thus recommended for the country. This is the only way forward for any fiscal policy of the government to achieve its objectives, especially in promoting economic growth and reducing poverty.
\end{abstract}

Keywords: budgeting, economic growth, fiscal policy, poverty, poverty alleviation

\section{Introduction}

One of the reasons why governments all over the world intervene and participate in the working of an economy is to enhance efficient allocation of resources. Over time, government involvement has increased in absolute and relative terms, especially in developing countries were the mechanism of market forces have proved insufficient and ineffective in achieving macroeconomic objectives. The efficiency in the allocation of resources was expected to benefit the aggregate economy.

Musgrave and Musgrave (1989:5) highlights two reasons for public sector (government) involvement in the piloting the economy. One, it could be as a result of the governments' political and social ideologies which departs from the premises of consumer choice and decentralized decision making. Second, is the fact that the market mechanism alone cannot perform in all economic functions. To them, the first reason is minor, while the later is a major reason for public sector involvement in the economy. Thus the need for public policy that would guide, correct and supplement it in certain respects. They further assert that the fact remains that the proper size of the public sector is to a significant degree, a technical, rather than an ideological issue.

In the past, four decades, Nigeria's potential for growth and poverty reduction had remained unrealised. This was so despite the abundant mineral and material resources available in the country. The situation is so pathetic when compare to emerging nations like China, Malaysia, Singapore, India among other countries whom Nigeria was far ahead of in the sixties to early seventies. Many analysts including these authors have attributed the non performance of the Nigeria economy to corrupt bureaucracy, political instability, lack of transparency and accountability in 
governance and lack of visionary leaders that will take the economy on the part of inclusive growth and development (Asaju \& Yarie, 2013, Asaju\& Adagba, 2013 and Sanusi, 2010). The major constraint in this direction has remained the conduct of micro economic policies and total neglect of supply side issues, which remains critical to the advancement of the economy. These couple with misapplication of monetary and fiscal policies and complications in the adoptions of non-market friendly tools constituted major challenges to realising Nigeria's fiscal objectives.

According to Sanusi (2010: 4), the country has in the last one decade experience economic growth, but the growth has not been all inclusive, broad based and transformational. To him, the major drivers had been the agriculture and service sectors. The implications of these trend according to Sanusi is that the economic growth witnessed in Nigeria had not resulted in the desired structural changes that would make the manufacturing sector the engine of growth, create employment, promote technological development, and induce poverty alleviation.

The Nigerian Public Services have also remained inefficient in terms of service delivery. Infrastructural decay, high rate of corruption, and lack of transparency and accountability in the management of public policies and resources shows the depth of inefficient public sector that suppose to pilot the economy through fiscal policies. These have led to a rise in inflation, fall in growth and declining real incomes, and high rate of poverty.

The question is how can fiscal policy be made more effective to achieve the objective of economic growth and poverty reduction in Nigeria? The major objective of this paper is to examine the efficacy of fiscal policy especially the budget in promoting economic growth and poverty reduction in Nigeria.

The paper is divided into five sections, with the first been the introduction. Section two reviews the conceptual issues of fiscal policies, economic growth and poverty especially in Nigeria. Section three dwell on the subject matter, that is, how fiscal policies have been used to promote economic growth and poverty reduction. The last section contains the conclusive remarks and recommendations on the way forward.

This paper is a descriptive research using qualitative data from secondary sources. The content analysis was adopted in analysing the data.

\section{Theoretical Framework}

This study is hinged on Wagner's $(1962 ; 14)$ )" Law of increasing scale of public expenditure". The public sector plays a significant role in the management of an economy at all level as of development. This role is usually through its revenue and expenditure policy. The theory of public expenditure development posits that the role of public spending evolves in the course of development since the budgetary function must adapt to the changing needs of the economy. The varying needs of the economy relates to both the allocation and distribution perspectives of public expenditure. The allocation perspective deals with the rising share of the public sector in the economy. That is there is a statistical direct relationship between the growth in public sector size and the growth and development of an economy.

The premise of the theory is that in growing economies, the increasing scale of public expenditure naturally increases income. In order to justify this generalisation into a theoretical fashion, Wagner divides public expenditure into two categories, namely security (including internal and external) and those of welfare. As the level of development increases, the level of expenditure cannot remain constant. In many growing economy like Nigeria, the share of public sector in national income has been increasing. That is why the government's annual budget dictates the nature and direction of economic activities and the provision of social and economic services to meet the needs of the citizenry. But the question is that, has the increase in the level of public expenditure commensurate with the level and dimension of economic growth in Nigeria? Has this led to the reduction of poverty in the country? These questions are pertinent in view of the huge amounts of fund allocated for expenditures as reflected in the annual budgets in Nigeria.

\section{Conceptual Issues}

\subsection{Fiscal Policy}

Fiscal policy refer to the part of government policy concerning the raising of revenue through taxation and other means and deciding on the level and pattern of expenditure for the purpose of influencing economic activities or attaining some desirable macroeconomic goals (Anyanwu, 1997:249). Fiscal policy simply defined is the manipulation of government revenue through tax system, government expenditure and debt management to achieve pre-determined macro-economic objectives. Such fiscal policy can be used for allocation, stabilisation and distribution. In essence, a primary objective of fiscal policy is to balance the use of resources of the public and 
private sectors and by so doing avoid inflation, unemployment, balance of payments pressures and income inequality. Fiscal policy is traditionally administered by the Executive arm through the Ministry of Finance.

According to Wise Geek (2013) the effectiveness of fiscal policy depends on a wide range of factors which cannot be reliably predicted or understood in advance. Behavioural changes caused by changes in government spending and taxation are among the most significant determinants of effective fiscal policy. Other factors affecting the effectiveness of fiscal policy as identified by Wise Greek include, time lag between the implementation of a new policy and the realisation of effects of that policy; the effects policy changes have on interest rates and other economic concerns; and the actual quality of the policy change.

The goal of macroeconomic policy is to achieve target levels of inflation, unemployment and economic growth. Fiscal policy defines the scope and structure of services to be financed by the government, adjust the distribution of income through taxes and maintained stability of the economy so that these goals can be achieved if aggregate demand grows in pace with productive capacity. If aggregate demands does not expand more rapidly than productive capacity, inflationary pressures will increase. On the other hand, if aggregate demand does not expand as much as growth of productive capacity in the economy, there will be rising unemployment. Although many analysts have argued that an important issue is the conduct of macroeconomic policy is the optimal policy mix-a combination of monetary and fiscal policies to achieve the objectives of macroeconomic policy. To them, the question of monetary-fiscal policy mix arises because both policies are interrelated and mutually reinforcing thus suggesting that they are complementary. Furthermore, the effectiveness of one depends on the other.

The policy instrument for controlling demand is monetary policy which influences the supply of money and availability of credit and fiscal policy which affects the aggregate flow of purchasing power. Thus, aggregate demand can be influenced through the use of either fiscal or monetary policy. In fact, it is possible to achieve the same level of aggregate demand with different combinations of fiscal or monetary policies.

Monetary policy operates by changing money supply to affect indirectly the levels of prices, employment and growth. Fiscal policy, on the other hand affects aggregate demand by changing the income available to spending units in the economy and its impact will depend on the nature of government spending i.e. what goods government decides to buy, what taxes it decides to charge and what amount it decides to transfer. Any of these policies could affect the level of demand and cause an increase in consumption spending. Investment subsidy could also increase investment spending.

The appropriate impact of fiscal policy depends very much on the state of the economy. Fiscal policy is expected to be expansionary, if expected level of demand is low and restrictive, if expected pressure and demand is high in the light of government objectives. An expansionary fiscal policy involving higher government spending can crowd out some interest sensitive private sector spending. In a recession, an expansionary monetary policy complemented by fiscal stimulus is required to stimulate growth, output and unemployment. On the other hand, when an economy is over heated, tightening of fiscal and monetary policies is required. This assertion is in line with the Keynesian views of fiscal policy that expansionary and contracting fiscal policy can be used to influence macroeconomic performance.

Musgrave and Musgrave (1989:6) identify the following as the objectives of fiscal policy;

i. The provision of social goods, or the process by which total resource use is divided between private and social goods and by which the mix of social goods is chosen. They referred to this as allocation function.

ii. Adjustment of the distribution of income and wealth to ensure conformance with what society considers as "fair" or "just" state of distribution. This is referred to as distribution function.

iii. The use of budget policy as a tool for maintaining high employment, a reasonable degree of price level stability, and an appropriate rate of economic growth, with allowances for effects on trade and on the balance of payment. This is referred to as the stabilization function.

From the above assertions, it implies that the budgetary policy of a nation greatly determines the extent to which its macro- economic objectives are achieved. Thus, it can be postulate that there is a relationship between the budgetary policy of a nation and its economic growth and poverty reduction efforts.

\subsection{Budgeting}

A budget is a framework for revenue and expenditure outlays over a specified period, usually a year. Budgeting can be seen as setting of expenditure promise and the weighing of alternatives. It is a system of resources allocation. Hence it implies looking ahead and planning, since decisions involved in the process are of future orientation. In this 
sense, budgeting involves the converting of the multi-year plan of operations into more exact short-term instalments of inputs and outputs, usually for the year (Anyanwu, 1998:249). According to (Ekpo, 2010: 8) though all items in a budget are estimates (intentions), nonetheless, it is an instrument stipulating policies and programmes aimed at realising development objectives. Budget serves as an avenue through which government promote economic growth, ensure price stability, create employment, equitable distribution of wealth and poverty reduction and other fiscal objectives.

On a broader bases, therefore, the budgets is not only an instrument of economic and social policy but also a planning tool, instrument for coordination and an instrument for communication. Therefore, a good budget requires comprehensiveness, a meaningful presentation of the state of budgetary balance, an appropriate grouping of expenditure items (Anyanwu, 1997:249). As a political instrument, it states the philosophy, ideology, and agenda of government during the year which are derived from short, medium or long-time plans. The Nigerian budget is made of the projected revenue profile and expenditure. The revenue profile stipulates the amount and sources of expected revenues for the year. The expenditure profile shows what the revenue will be expended on.

\subsection{Economic Growth}

Economic growth is the increase in the amount of the goods and services produced by economy overtime (Wikipedia, 2011). It is an increase in the capacity of an economy to produce goods and services, compared from one period of time to another (Investopedia, 2013). It is measured as a percentage of gross domestic products GDP of a country. Economic growth can be measured in nominal of real term. In nominal term it include inflation, while in real term, adjustment are made for inflation to eliminate the distorting effect of the price of goods and services produced.

For the purpose of inter -country comparison, the GDP or GNP per capita income is used due to the fact that they take into account the population differences of these countries.

In recent times economic growth has been associated with technological changes in a country. Economic growth is not only associated with an increased productive capacity, but an improvement in the quality of life of the people of the economy. For instance in Nigeria, the economy is said to have experienced an increase in productive capacity, but this increase has not resulted in the improvement in the quality of life of the citizenry. The majority of Nigerian still wallowed in abject poverty.

\subsection{Concept of Poverty}

The concept of poverty does not lean to a specific definition due to the fact that it is multidimensional in nature. Poverty is defined by the (World Bank: 2004:2) as a pronounced deprivation in well-being, and comprises of many dimensions. It includes low incomes and inability to acquire the basic goods and services necessary for survival with dignity. It also encompasses low levels of health and education, poor access to clean water, and sanitation, inadequate physical security, lack of voice, and insufficient capacity and opportunity to better ones life (World Bank, 2004: 2).

Poverty is a denial of choices and opportunities, a violation of human dignity. It means lack of basic capacity to participate effectively in society. It means not having enough to feed and clothe a family; not having a school or clinic to go to; not having the land on which to grow ones food or a job to earn ones living; not having access to credit. It means insecurity, powerlessness and exclusion of individuals, households and communities. It means susceptibility to violence, and it often implied living in marginal or fragile environments, without access to clean water and sanitation (UNDP, 2009: 2-3).

Statistics show that poverty has been on the increase in Nigeria since 1980 . Poverty rate rose from $27 \%$ in 1980 to $46 \%$ in 1986. Due to the significant growth and economic recovery witnessed from 1985 to 1992 , poverty rate declined to $40 \%$ in 1992 . It rose sharply again to $66 \%$ in 1996 , and increased further to $69.2 \%$ in 1997 . By 1999 , it was estimated that more than $70 \%$ of the population were poor (FOS. 1996, 1999, 2004, CBN, 1999). As at 2004, poverty rate declined to $54.4 \%$ (nbs, 2005). The 2008/2009 UNDP Report indicated that $70.6 \%$ live below the poverty line (Analysis, 2010: 9). As at 2011, Poverty incidence in Nigeria is over 70\% (CBN, 2011).

One common explanation for the persistence of poverty all over the world is the absence of natural endowments. But the case in Nigeria is an irony. The fact remains that the funds that have accrued from the abundant mineral and natural resources in Nigeria would have made the country one of the richest in the world. But majority of Nigerian citizens still wallowed in poverty Also, efforts made by the government and other concerned agencies to reduce this malaise have yielded no positive impact as the incidence of poverty has continued to rise. The poverty situation in Nigeria is further aggravated by lack of or insufficient access to necessary social goods and services, high rate of unemployment caused by inefficient allocation of resources of the state. The major reason that can be adduced for 
the above is the high rate of corruption, especially the misappropriation and outright embezzlement of fund accruing from the wealth of the nation and lack of good governance in the country. Considering the above fact, the best strategy for alleviating poverty and enhancing economy growth is through an effective and efficient fiscal measure.

\section{Fiscal Policy in Nigeria: Problems and Prospects}

Over the years, the fiscal policy has been the most important instrument influencing macroeconomic performance in Nigeria. The importance of having virile fiscal policies in Nigeria has continued to be the major focus of successive governments in Nigeria including the Obasanjo administration. In his 2001 independent day anniversary speech, President Obasanjo re-emphasised that the government in pursuance of a virile fiscal policy is sending a Bill (Fiscal Responsibility Bill) for an Act that would seek to strengthen the fiscal and monetary management at the national level. According to him, while all levels of government local state and federal have a joint responsibility for managing the nation's economy, the federal government must play a pivotal role in this regard for the benefit of all Nigerians, no matter where they reside. To him, the modest achievements have been eroded by what remains to be done; that is ensuring a virile fiscal policy. He further elaborated on their failure thus:

Despite out determined effort in the area of poverty eradication, two many of our citizens still remain poor. Our industries are being revived and government have taken many measures to support them, but industrial capacity is still far below the level we will like to see. Inflation is still high with us, though today, it is not alarming as it used to be. All need to apply our collective will and resources so that every day, every year, we can look back and see how much more value we have added to our circumstances (Vanguard, 2002).

Other problems include inefficient use of resources, waste and misplaced priorities in government expenditure, high fiscal deficits at all tiers of government, weak institutional structure among others. These problems have led to a heavy debt burden, huge recurrent expenditure, inefficient public service delivery etc. Also, government spent a huge proportion of current revenue in debt-servicing and interest payment. The Fiscal Responsibility Act is currently been implemented at the federal level with little result to show for it. The rate of corruption is still high and pervasive at the federal level and the virtue of transparency and accountability is been grossly abused and undermined by Public officers.

Furthermore, the budget process reached the point of near collapse before the democratic government came to power. The problem has to do with lack of political will and commitment to abide by stipulated rules and budget guidelines. As, such, it was difficult for the government to achieved their major fiscal objectives. Fiscal objectives are macro-economic goals that the government intend to achieve using the various fiscal policies within a time period.

\section{Fiscal Policy Objectives and Measures in Promoting Economic Growth and Poverty Reduction from 2000-2012}

Nigeria fiscal policy objectives during the period 2000-2012 can be distilled from the macroeconomics policy of 2001-2003 and 2003-2005 National Rolling Plans, National Economic Empowerment Strategies (NEEDS), Seven-Point Agenda, Transformation Agenda as well as various annual federal government budgets. The major fiscal policy objectives within the year under review are reduction of unemployment, poverty and inflation. To achieve these objectives, profound attention is paid to infrastructure e.g. roads, power; water supply, agriculture, education, health, and national security as well as laying a solid-foundation for a private sector led market-driven and growth-enhancing economy. Specific objectives include:

$>$ To provide the enabling legal, fiscal and monetary environment for the private sector to become the engine of growth.

$>$ Enhancing performance of infrastructural facilities through proper rehabilitation and maintenance of existing infrastructures, and the provision of additional facilities, particularly, water and energy.\#

$>$ To improve the operational capabilities of the law enforcement agencies at crime prevention and reduction.

$>$ To continue with the policy of probity, transparency and accountability in order to reduce the cost of doing business.

$>$ Pursing low interest rate regime.

$>$ Minimising budget deficit and eliminate extra budgetary expenditure.

$>$ Targeting a moderate inflation rate.

$>$ Striving towards a GDP growth rate of at least 5 percent.

$>$ Continuation of privatisation of government investment and public utilities. 
Focus on an external debt management approach that builds confidence through negotiation and consultation. For possible reduction in aggregate debt levels and debt services cost in the context of a medium-term economic programmes.

In view of the above objectives, can it be said that these objectives have been achieved? The study examined the extent to which the above objectives have been achieved to promote economic growth and poverty reduction.

The economic growth of a nation could be easily accessed by the stability of the macro-economic parameters such as the GDP growth rate, and the inflationary rates. However, the inflationary rates have been unstable and sector growth uneven. GDP growth rates were 3.8 and 3.9 in 2000 and 2001 respectively, relative to population growth rate of 3.0 and 3.1 percent. This implied that for the two years, real Gross Domestic Product (GDP) grew faster than population rate, implying a net addition to the nation's store of value. (Obasanjo, 1999, 2001)

Furthermore, the real Gross domestic Product (GDP) growth rate which averaged 6.29 per cent between 2004 and 2007 declined marginally to 5.99 per cent in 2008 rising thereafter to 6.9 percent in 2009 . This was attributed to the impressive performance of the non-oil sector, particularly, agriculture and the continuous implementation of sound macroeconomic policies. (Sanusi, 2010:9a)

It is well known that inflation rates affect the incidence of poverty and per capital consumption. Higher inflation rates causes significant erosion in the purchasing power and thus increase poverty. The primary target of the government was to lower the inflation rate. As revealed (C. B. N, FOS 2004) statistics, inflation rate accelerated from 6.9 percent in 2000 to 18.9 percent in 2001, it reduced to 15.6 percent in 2002, it increased to 17.5 percent in 2005. In 2009 inflation rate fell from 13.9 percent to 13.4 percent in 2010 (Ojo, 2011). This trend of inflationary rate is contrary to the proposed target of 9 percent inflation rate.

In other to ensure sustainable economic growth and poverty reduction, the government within the year under review have vigorously pursued budget discipline. It emphasised a fiscal rule that stabilises the level of expenditure at all levels of government and as well ensure the budget is predictable and divided between recurrent and capital expenditures. To this effect, the budget will move away from a situation where the recurrent expenditure consumes the entire government revenue. However data below indicates that the country is yet to achieve these objectives. From 2000-2005, capital expenditure was less than recurrent expenditure. In 2000, recurrent expenditure was N256, $336,677,292$ and recurrent was N508, 768,350,687.00 in 2005, and recurrent expenditure was N651billion or $40 \%$ of the budget (Obasanjo, 1999, 2006)

In 2007, capital expenditure was N781 billion representing an increase of 38.1 percent over that of 2006. This constitutes 43 percent of the total budget. The recurrent expenditure was N1.057 trillion representing 57 percent of the budget. The recurrent expenditure for year 2008 was N1, 352.9 representing 56 percent of the budget, while capital expenditure was N860.3billion. In 2009, recurrent expenditure was 1,523.9 trillion, while the capital expenditure was N552.2 billion. Out of the N4.07 trillion proposed for 2010, N1.37 trillion was earmarked for capital expenditure, N2, 011 trillion was proposed for recurrent expenditure. As at 2012, the total expenditure was N4.2 trillion out of which N1, 320 trillion was for capital expenditure, while N2.470 trillion was for recurrent expenditure (Obasanjo, 2006, Nigerian Business, 2007, FGN 2009, Jonathan 2011, Ojo, 2011, Tella 2012, Voodoo Doll, 2012)

The above statistics showed that recurrent expenditure has continued to take a larger part of the entire government expenditure. In an attempt to curtail the high recurrent expenditure, the government sought to create a civil service that will be smaller, highly skilled, motivated and more productive. The government also continued with its privatisation programmes to reduce government participation in some economic activities that could be properly handled by the private sector.

It is however disheartened to know that salaries and other emolument of workers have continued to take a larger part of the recurrent expenditures of the budgets. The recent disagreement between the federal legislatures and the executive over the high rate of recurrent expenditure in the 2013 budget testify to this. The minister of finance in her remark exercised the fear that if the recurrent expenditure remains as drastically slashed by the legislature, the government might not be able to pay federal government workers' salaries by October this year. Asaju (2012:56-64) had argued that as far as more than 50 percent of the annual budget is spent for administrative purposes, it might be difficult for Nigeria to achieve any economic development goal, including Vision20:2020.

In other to accelerate economic development, the government over the years have attempted to diversify the revenue and productive base of the economy from oil through appropriate fiscal incentives to investment in agro-allied industries, gas, solid minerals, petrochemical industries and tourism. Also priority was given to sectors of the 
economy that can best spur economic diversification, job creation and poverty reduction. These include, power and steel, agriculture, solid minerals, education, health, and works and housing in the capital budgets.

Within the year under review, the oil sector recorded a positive variance while the non oil sector showed a negative variance. In 2001, the oil sector recorded a variance of N108 billion, while non-oil had a negative variance of N16 billion. As at 2002, the total collectible revenue was N1.16billion, with revenue from oil estimated at N5445.7billion, while non-oil was projected at N513.3billion. In 2003 fiscal year, the total estimated federal collected revenue was N1.819.0124 billion. Oil revenue was estimated at 1,120,1789 billion naira, total non-oil revenue was projected at 635.8335 billion. As at 2005, the estimated federally collectible revenue was N3, 619 billion of which N2, 902 billion was oil revenues, 563 billion of non-oil taxes, and 100 billion of independent revenue. In 2007, the total budget was N2.3 trillion, oil revenue constituted N1.1 trillion, while non-oil was estimated at N1.1 trillion. In 2008, out of the N4.439 trillion projected, oil revenue was N3.629 trillion, constituting $80 \%$ of the total revenue. Non-oil revenue was N0.91 trillion, which was 20 percent of the total revenue. ( New Nigerian Newspaper, 2001, 2002, FGN, 2005, Nigerian Business com, Yar'Adua, 2007)

This trend indicates that the other sectors (non oil) of the economy have not grown and efficient enough to contribute positively to the total revenue of the economy. This could have impacted positively on economic growth and poverty alleviation efforts in Nigeria. It is pertinent to note that the growth of other important sectors, like agriculture, industrial and manufacturing, power and mines, solid minerals, transport e.t.c would apart from creating employment activate economic growth.

Furthermore, the government seems to continue its dream of budget surplus, i.e. revenue excess over expenditure. Government rationale for surplus budgeting was to convince the international financial Institutions that its Fiscal position is healthy. In 2000, the revenue budget surplus was N376 as a total revenue projection of N1.156 trillion. This was different from the government budgeted N523 billion of a total amount of 1.4 trillion. The government even recorded an overshot of the revenue projection of 2001 fiscal year by about 100 billion as it was later indicated that the federal collected revenue amounted to N.5 trillion. In 2002, the country experienced a short fall of N209, 058 billion naira. From 2003-2005, the government recorded an over shot of the budgeted revenue. But despite this overshoot the budget deficit was mounting as against the budget surplus (Obasanjo, 2001, New Nigerian Newspaper, 2001, 2002, FGN, 2005).

On the government intention to minimise budget deficit and eliminate extra-budgetary expenditure, the government have not achieved much success within the years under review. This could be attributed to lack of fiscal discipline. Despite the fact that realised revenue was often above budgetary estimates, extra-budgetary expenditure have been rising so fast and resulting in even bigger fiscal deficit. There has been an increasing concern over the unfavourable effect on productive capital stock of persistence and large government deficits, which inevitably has resulted in increased government debt as a ratio of G.D.P and total private wealth. Other effects of huge budget deficit include, huge recurrent expenditure burden at all tiers of government, inefficient public delivery services, and the distortions in the incentive structures for both the private and public sector.

According to 2002 Annual Report of the Central Bank of Nigeria (CBN), the federal government budget deficit as at 2000 was N82.7 billion or 2.2 percent of GDP. In 2001, budget deficit was N422.1 billion 4.0 percent of the GDP In 2002, it was N301.4 billion or 5.1 percent of GDP, and as at 2005, budget deficit was N314 billion or 0.8 percent of GDP. In 2006, budget deficit was $-2.6 \%$ of GDP, it rose to -3.7 in 2007. It however declined to $-2.5 \%$ in 2008 and 2009. As at 2011, the budget deficit increased to $2.9 \%$ and decreased to $2.8 \%$ of GDP in 2012. (Reuters, 2007, Yar'Adua, 2007, Tella, 2012)

It is pertinent to note that nothing is wrong with budget deficit per se, the major problem is the source of financing the deficit (especially monetary financing) and on what the deficit is spent on (whether productive or non productive items).

Currently, all tiers of government spend more than they earn, cumulative deficit over the five years alone stands at more than N1 trillion, excluding arrears of pensions and gratuities and debt to local contractors. With foreign debt of about $\$ 31$ billion in 2001 fiscal year, (in a $\$ 45$ billion economy), the government spend a huge proportion of recurrent revenue in debt-servicing and interest payments (NEED, 2004). The Stock of public debt of the federal government rose by 4.9 percent in 2001 at N4.193.3 billion representing 76.4 percent of GDP. External debt service was N170 billion, while N186 billion was used for domestic debt services.

However, in 2006, the government through negotiation and consultation with Paris Club got a debt relief gains amounting to 110 billion naira, which the government promised to channel into carefully selected poverty reduction 
initiatives and programmes in health, education, water, power, housing and agriculture. Despite the debt relief, the debt profile is still very high and the amounts used in servicing the debt have continued to increase. The domestic debt as 2008 was N1.9 trillion for domestic debt and US\$3billion for external debt down from about US\$32billion in 2005. As at December, 2009, domestic debt amounted toN3, 228.03, while external debt was US\$3,947.30 million (Yar'Adua, 2008, Budget Office, 2010).

The amounts used for debt services have continued to rise, from N326 billion in 2007 to N372.3 billion in 2008, constituting an increase of 25.3 percent. It rose to N436.2 billion in 2009. It increased further to N497.7 in 2010 and as at 2012 it was N560 billion. The major effect of huge debt is that, the amount used for serving the debt which most times constituted a substantial amount of the budget would have been used or channelled to other sectors of the economy that would have enhanced economy growth and poverty reduction.

\section{Conclusion/Recommendations}

A cursory comparison of the fiscal objective and policies of the federal government in promoting economic growth and poverty reduction in Nigeria from 2000-2012 have shown that the successes have been low. Even though, the country has in recent times experienced an increase in GDP growth rate, the government have not been able to achieve the targeted growth rate, when other nations of the world are achieving more than 10 percent growth rate. Despite the relative growth experienced in some sectors (i.e. Agriculture and service industries) of the economy, these growths have not accentuated into a healthy and better environment for economic growth as important sectors like the manufacturing and industrial sectors are still at a rudimental stage. Also, the impacts have not resulted in poverty reduction, as the poverty incidence has continued to rise and the standard of living of the populace also continued to deteriorate.

Furthermore, the economic growth recorded has not been inclusive and have not made the desired impact on the citizenry as the poverty rate is still high. The budgets during the years under review as revealed in the study have not achieved the fiscal objective of reducing unemployment, poverty and inflation. The government have not been able to achieve the targeted reduction in the inflation rate and increase in GDP. The recurrent expenditure still takes a larger portion of the total budget. The government still continued with budget deficits even when the targeted prices of crude oil are most time overshot. The debt profile has continued to increased overtime, especially domestic debt, forcing the country to spent substantial part of its annual budget in servicing debt. Also, the oil sector still dominates the revenue profile, indicating the deficiency in other sectors of the economy which are supposed to be the driving forces of the economy.

Apart from these deficiency in the structure and content of the budgets, other problems such as late approval of budget by the National Assembly, late disbursement of fund, poor and lack of full implementation of budget, corruption, among others make the achievements of the budget objectives, especially poverty reduction very difficult or unrealisable.

In view of this, the government should ensure a strict fiscal policy discipline. Also government need to demonstrate high level of commitment to policy consistency and implementation. The Programme Project Budgeting system should be adopted by the government. This apart from enhancing effective implementation and monitoring of budgeted funds will reduce corruption. It will also lead to greater transparency and accountability in the utilisation of the budget. This is the way forward to ensure a fiscal policy that would not only promote economic growth, but as well better or improve the standard of living of the general citizenry.

As Obasanjo has rightly said, "national economic growth must be pursed relentlessly, but at the same time we must ensure fair and reasonable distribution of its fruits". As such, an effective fiscal policy in Nigeria is imperative for economic growth and poverty reduction.

\section{References}

Aliyu, A. (1998). Small and Micro-Enterprises in the Alleviation of Poverty. Paper presented at the 1998 Technology Summit, Abuja.

Amahionyeodiwe, A.H. (1999). Fiscal Federalism, Health Care Spending and National Development: The Nigeria Experience. Nigerian Journal of Economic and Social Studies, 4(2).

Anyanwu, C.J. (1997). Nigeria Public Finance. Onitsha: Joanne Educational Publishers Ltd.

Asaju, K. (2010). Vision20:2020: Realities and Challenges, Faculty of Administration, Nasarawa State University, Keffi. Nigeria. Conference Proceeding, Vol. 1. 
Asaju, K., Adagba, S.O., \& Anyio, F.S. (2013). Corruption and service delivery: the case of Nigerian public service. Wudpecker Journal of Public Administration, 1(1).

Asaju, K., Adagba, S.O., \& Yarie, E. (2013). Global Financial Crisis and Economic Development in Nigeria: The Challenges of Vision20:2020. Journal of Economics and Sustainable Development, 4(4).

Baiye, C., Abu, S., \& Adaba, T. (Eds). (2002). Nigeria 2003: Politics, Economy and Business. Lagos: Verify Communication Limited.

Budget Office of the Federation. (2010). 2010 First Quarter Budget implementation Report. Budget Office of the Federation, Federal Ministry of Finance, Abuja

Business and Economy. (2001). Fiscal and Monetary Policies in Nigeria. New Nigerian Newspaper, December 12, P.5.

Business Vanguards. (2002). Federal Government's Economic Recovery Programme 2003-2007. Vanguard Newspaper, Wednesday, October 23, P.19.

Central Bank of Nigeria. (1999). Nigeria's Development Prospects Poverty Assessment and Alleviation study.

Economics and Politics. (2006). Nigeria's N2.3 Trillion Budget for 2007. The Nigeria Business.com

Ekpo, H.A. (2010). Nigeria and its Budgeting Expenditures Dilemma. Business Journal. Retrieved from www.bsjournal.com

Federal Government of Nigeria (FGN). (2005). Poverty Profile for Nigeria. Abuja: National Bureau of Statistics (NBC).

Federal Government of Nigeria. (2008). Federal government of Nigeria 2009 Budget preparation and submission of call circular.

Federal Office of Statistic (FOS). National Consumer Survey, 1985/86 and 1992/93.

Federal Republic of Nigeria. (2005). 2005 Budget Speech by his Exellency President Olusegun Obasanjo at the Joint Session of the National Assembly. Tuesday, October 12, 2004.

Investopedia. (2013). Economic Growth Investoped. Retrieved from www.investopedia.com/terms/e/economicgrowth.asp

Liden, D. (2013). What Factors Influence the Effectiveness of Fiscal Policy? Wise GEEK. Retrieved from https://twitter.com/wiseGE

Mohammed.. (2010). Poverty in the Midst of Plenty. Analysis Magazine, 6(2).

Musgrave, R.A., \& P.B Musgrave. (1989). Public Finance in Theory and Practise (5 ${ }^{\text {th }}$ ed.). New York: McGraw Hill.

National Planning Commission. (2004). National Economic Empowerment and Development Strategy (NEEDS) National Planning Commission, Abuja.

Obasanjo, O. (1999). 2000 Budget Policy Thrust delivery by the President Olusegun Obasanjo to the Joint Session of the National Assembly, Abuja on Tuesday, November 30, 1999. New Nigerian Newspaper, Wednesday, December 1.

Obasanjo, O. (2001). Wants Virile Fiscal Policies. Vanguard Newspaper, $2^{\text {nd }}$ October, P.1.

Obasanjo, O. (2002). Obasanjo's Value-For- Money 2003 Budget.A full text of the address by President Olusegun Obasanjo on the occasion of the presentation of the Fiscal 2003 Appropriation Bill at a Joint Session of the National Assembly, Abuja on $20^{\text {th }}$ November, 2002. New Nigerian Newspaper, Thursday, November 22.

Obasanjo, O. (2002). Terrorist Attacks on U.S Affect Economy. A text of the 2002 Budget delivered by President Olusegun Obasanjo to the Joint Session of the National Assembly on Wednesday, 1 November, 7. 2007. The Punch Newspaper, November 9, P.13.

Obasanjo, O. (2006). 2007 Budget Proposals presented by President Olusegun Obasanjo at the Joint Session of the National Assembly, Abuja on Wednesday, October 11, 2006. New Nigerian Newspaper, Thursday, October 12.

Ochinma, V. (2009). Nigeria: what with Budget failure. The TIDE Newspaper. Retrieved July 16, 2013, from www.thetidenewsonline.com

Ogbuke, Chinwe. (2002). 2003: FEC Approves Framework. The Punch Newspaper, September 13, P.17. 
Ojo, J. (2011). Review of Nigeria's 2011 Budget. Awesome Inc.template.

Reuters. (2007). Nigerian Budget figures for 2006-2008. Retrieved from TABLE-Nigerian\%20budget $\% 20$ figures\%for\%202006-2008\%20\%20\%20Reuters.htm

Sanusi, L.S. (2010). Global Financial Meltdown and the reforms in the Nigerian Banking Sector. Paper delivered in a Public lecture at the convocation square, Abubakar Tafawa Balewa University, Bauchi. Nigeria. Research Department, Central Bank of Nigeria.

Sanusi, L.S. (2010). Growth Prospects for the Nigerian Economy. Paper delivered in a Public lecture at the Igbenedion University Eighth Convocation Ceremony, Okada, Edo State. Nigeria. Research Department, Central Bank of Nigeria.

Siyanbola Tomori. (Ed.). (1999). Economic Policy Watch. The Nigerian Association of Chambers of Commerce, Industry, Mines and Agriculture Lagos, No. 2.

SummyShow. (2010). Nigeria 2010 Budget Breakdown. Expert Column. ALL CONTENT COPYRIGHT@ 2009-2013BY EXPERTS COLLUMN.COM

Tella, A.S. (2012). The Nigerian 2012 Budget: A critical Appraisal. Paper presented at the state of the nation Roundtable organised by the patriots for New Nigeria Initiative (PNMI) at PNMI secretariat, Wuse, Abuja on Thursday, March 8, 2013.

United Nations Development Programme UNDP. (2009). Indicators of Poverty \& Hunger. In 'Poverty' Wikipedia, the free encyclopaedia. mht. Retrieved 3/31/2011.

Wikipedia. (2011). Economic Growth. Wikipedia, the free encyclopedia. Retrieved from https://en.wikipedia.com/terms/e/economicgrowth

World Bank. (2004). Poverty and Inequality Analysis. In 'Poverty'. Wikipedia, the free encyclopaedia. mht. Retrieved 3/31/2011.

Yar'Adua, M.U. (2007). 2008 Budget Speech Presented at the Joint Session of the National Assembly, Abuja Thursday, November, 2007. 